\title{
Study on the Opportunities and Challenges of College English Teaching in the Era of MOOC
}

\author{
Zhang Yan \\ College English Teaching Department of Zaozhuang University \\ Bei an road, Shizhong district, Zaozhuang city, Shandong province
}

\begin{abstract}
English is the most widely used language in international cultural exchanges. Therefore, the current education field attaches great importance to English teaching. In order to improve the overall quality of English teaching and reduce the burden of English teaching, relevant English education researchers have proposed a new type of education"Mu class". With the advent of the era of MOOC, traditional English teaching has been further improved and perfected. Abandoning backward teaching methods and learning new teaching methods, the content of "Mu Class" has promoted the development of English education in colleges and universities. This paper briefly describes the changes of English teaching philosophy in colleges and universities and the opportunities and challenges encountered in the innovation process in the era of MOOC.
\end{abstract}

Keywords-MOOC; Opportunity and challenges, Development method

\section{INTRODUCTION}

The MOOC began in the United States in 2011. Although there have been related research before, there is no strict definition of the MOOC. The word "MUOC" is transliterated from the English "MOOC", which is called "massive open online course", which is a large-scale open course. This course is different from traditional classroom teaching. Its biggest feature is that it breaks the traditional classroom time. With geographical restrictions, students from different regions can learn at any time they want to study, and can search for their biased knowledge on the Internet. This kind of teaching mode enables students from all over the world to gather together to discuss academic issues, and to share learning resources and think collisions, so as to improve learning efficiency and effectiveness. In the fall of 2011, Stanford University officially opened a free introduction to artificial intelligence, which attracted the registration of 160,000 college students around the world, which laid the foundation for the development of the MOOC and became popular all over the world. As far as the admiration class is concerned, China's quality education is still relatively backward, and it is still in the initial stage of development. However, compared with the traditional teaching mode, the advantages of MOOC teaching are still very obvious, and in the current application, the advantages and characteristics of the class are constantly highlighted, and good teaching results have been achieved. The traditional teaching mode is too singular and boring. The students' learning is limited by time and space. The time in class is tight. There is no opportunity and time to communicate with teachers alone. This leaves a lot of loopholes in learning. The teaching model wastes classroom resources and at the same time greatly reduces the effectiveness of teaching. The MOOC mode basically overcomes this drawback, realizes online communication and communication, enables learning resources to be fully utilized, and achieves the goal of high efficiency and high standards of education.

In the application of MOOC teaching mode, the platform corresponding to this model contains a lot of rich basic courses in English. These basic courses are designed by experts in English teaching, so these courses are planned by ordinary English teachers in colleges and universities. There are certain differences in the teaching curriculum, and it is the existence of these differences that further highlights the superiority of the curriculum in the MOOC platform. One of the most striking aspects of the curriculum in the platform is to bring the English learning path from the class to the extracurricular. Moreover, MOOC teaching is also free to open to English learners around the world. Under such convenient conditions, English learners can determine their own learning progress and choose learning content. This kind of English teaching mode makes up for the shortcomings in traditional teaching. The emergence of this new teaching mode provides a new way for the development of English teaching. Although there is no clear qualification requirement for the MOOC teaching mode, the English courses offered in the MOOC platform are beyond the scope of Chinese college students' ability to accept learning. Under such circumstances, the English teaching in our country has sounded the alarm, and it is imperative to reform the traditional English teaching.

\section{ANALYSIS OF THE CHALLENGES FACED BY COLLEGE ENGLISH TEACHING IN THE AGE OF MOOC}

In the era when the teaching mode of MOOC is widely used, the corresponding teaching platform has a very rich foundation course in English, which is designed by English research experts. For this reason, there are many differences between the English courses in the platform and the basic courses applied by ordinary universities. It is precisely because of the many differences on the platform that the superiority of the platform is highlighted. The most obvious advantage of the corresponding platform of the MOOC is that it effectively broadens the English learning path and broadens 
the limit of breaking through the classroom learning time. In such an environment, it undoubtedly brings great challenges to college English teaching. Teaching resources are relatively scarce. With the continuous deepening and development of education reform, MOOC has attracted many college teachers and students with its characteristics of quality, autonomy and diversification. Because traditional English teaching is often based on the teaching mode of the book, it not only makes the teaching abnormally boring, but also easily attacks students' interest in learning English. With the application of the MOOC platform, the learning methods available to students will also increase. They can use multimedia, projectors, computers, etc. to conduct video and audio learning, and students can arrange their own courses, which is easy to stimulate their own learning. Interest, reduce learning exhaustion. However, when colleges and universities apply the classroom platform, it can not create a relaxed and happy class style, school spirit, and can not improve students' communication skills and management skills. At the same time, although college education has achieved great teaching results, there are still many colleges and universities whose teaching resources are still scarce. Multimedia software and related video and audio playback software have not been widely popularized, making it in the era of MOOC. College English teaching is also facing enormous challenges. To this end, in the era of MOOC, colleges and universities should strengthen the introduction of teaching resources and make reasonable use of teaching resources to carry out teaching. For example, when you explain an English article in an English class, you can use audio equipment to develop your students' listening skills. Or teachers can use the content of English texts to make use of multimedia production or find relevant videos to improve students' interest in classroom learning and learning efficiency.

Lack of excellent teachers. In traditional teaching, the leader of college English teaching is the teacher, and the teacher determines the content and method of classroom teaching. However, in the era of MOOC, it is more advocated that students study independently and arrange their own learning time independently. Because of the use of the platform of the MOOC, they have the characteristics of low cost, good teaching effect and high authority. It makes the English teaching of colleges and universities in the era of MOOCs into a great dilemma and has to change the teaching mode. However, the change of English teaching mode is not only time-consuming and difficult, but also has very strict requirements for the teaching level and quality of English teachers in colleges and universities. At present, many college English teachers are trying hard to change their teaching concepts, but they can't use the teaching methods reasonably when teaching under the platform of the MOOC. They should take into account the overall teaching effect, improve the teaching atmosphere, and adapt to the development of the times. Students' learning characteristics and interests are reasonably taught. To this end, in the era of MOOC, college English teachers should constantly change their teaching concepts, conduct self-learning and consult excellent teachers, constantly improve their English literacy and English teaching ability, and impart knowledge to students in the most appropriate way. Help them grow. At the same time, colleges and universities should also strengthen the training and recruitment of quality teachers, create good teaching conditions, and improve the quality of teaching.

\section{ANALYSIS OF THE OPPORTUNITY OF COLLEGE ENGLISH TEACHING REFORM IN THE AGE OF MOOC}

In the above analysis, we can understand that under the era of MOOC, China's college English teaching faces enormous challenges. At the same time, under the era of MOOC, there are also many opportunities for college English teaching. Only by seizing the opportunity can the university implement effective reform and innovation, which will help promote the development of English teaching in colleges and universities. Look at the English teaching plan with a new look. In the process of college English teaching, English teaching planning is a very important part, which has a direct impact on the effectiveness of English teaching. To this end, college English teaching reform in the era of MOOCs should start with English teaching planning. It is worth noting that in the planning process, the role of the English protagonist must not be neglected, that is, in the process of teaching MOOC, it is necessary to fully recognize the importance of English. With the advent of the era of MOOC, the idea that English teaching is centered on exams should be abandoned, but the cultivation of students' comprehensive English ability should be emphasized. To this end, college English teaching needs to be repositioned. Specifically, in the era of MOOC, for nonEnglish majors, learning English is only to gain more comprehensive ability and to improve their future job search. Advantage. For English majors, learning English is mainly to improve their intercultural communication skills. There is a fundamental difference between the two. It can be seen that in the English teaching planning of colleges and universities, it is necessary to treat them differently in order to effectively promote the reform of college English teaching in the era of MOOC.

Promote the professional development of English teachers. The advent of the era of MOOCs has prompted people to have a new understanding of college English courses, and there has been a tremendous change in this understanding and previous understanding. However, among the many changes, the most influential ones are college English teachers. College English teachers are not only the first-line transmitter of English knowledge, but also the performers and managers of English teaching work. It can be seen that college English teachers have a direct relationship with college English teaching reform. In the past college English teaching process, college English teachers must meet the status quo. The advent of the era of MOOCs has caused great changes in the understanding of English teachers in colleges and universities. The traditional methods of teaching are difficult to meet the actual needs of college English teaching in the era of elementary school. Teaching reform is imperative. Therefore, in the era of MOOC, the professional development of college English teachers has been greatly impacted. In order to meet the actual needs, college English teachers can continuously enhance their professional knowledge and comprehensive ability through systematic training, and can continue through the MOOC platform. Learn. In addition, under the era of MOOC, college 
English teachers use MOOC teaching, which helps to improve their information ability and enhance team awareness. All in all, the advent of the era of the class has effectively promoted the professional development of English teachers. 3. Promote the balanced development of English teaching. At present, the distribution of English teaching resources in colleges and universities in China is extremely uneven. Specifically, with the development of social economy and the continuous deepening of educational reform, some economically developed regions have abundant English teaching resources and high overall English teaching. However, in some areas with less developed economies, English teaching resources are seriously lacking, and teachers are insufficient. Due to this unbalanced distribution of English teaching resources, the development of English education in colleges and universities in China has been subject to many restrictions, and the overall teaching quality is relatively uneven. With the advent of the era of MOOC, this situation has been effectively changed. It is mainly through the platform of the MOOC that enables English teaching resources to be shared nationwide, so that every student and teacher can obtain the same teaching resources. In this way, there will be no problem of uneven distribution of teaching resources, breaking the regional restrictions on English educational resources, and contributing to the balanced development of English teaching in China.

\section{THE COUNTERMEASURES OF COLLEGE ENGLISH TEACHING IN THE ERA OF MOOC}

With the rapid development of Internet information technology, college English teaching in the era of MOOCs should also be integrated into fresh blood, find its advantages from the MOOC, and combine with the English teaching situation of the university to innovate, thus integrating one in a targeted manner. A set of programs suitable for English teaching in the school. Among them, the design and production of English micro-curriculum is one of the necessary measures in the reform of English teaching in colleges and universities. The micro-class mainly uses microvideo to spread English knowledge, so that students can accept and understand the core points of English knowledge in a short time. Therefore, the scientific and effective design of the micro-course is very necessary. In the teaching of MOOC, it is necessary to carry out rigorous design of the micro-courses, because the MO-class teaching mainly uses video as the main carrier to record the short and complete teaching activities of teachers around spoken English. For the general colleges and universities, the schools have professional high-definition video classrooms. For this, the micro-courses in the MO-class teaching can be recorded by the college video classroom. The video production is mainly divided into four stages: teaching preparation, recording video, Edit processing and publishing videos. Classroom real shots, interviews, discussion styles, and PPT animations are often used. The MOOC team must strengthen mutual cooperation, make full use of modern teaching technology to make micro-video production, and effectively strengthen and ensure the production and editing of micro-video. In addition, the release of MOOCs should be strictly based on the progress of college English teaching. Let the teaching and educational value of the MOOC be maximized. In addition, MOOC's micro-video should fully highlight its short features, allowing students to get the maximum amount of knowledge in the shortest time frame. The time of a single video should be controlled within 5-15 minutes to ensure the communication core. At the same time, the knowledge points reduce the cumbersome teaching steps. The beginning of the video should also mark the author, the unit and the applicable objects. In addition, the content of the video must have subtitles, and ensure the clarity and stability of the video, as much as possible into the common formats such as flv, rmvb and wmv, so that students can download and learn.

Under the era of MOOC, college English teaching mode must be thoroughly reformed and transformed. With the support of the Internet, teachers should not only pay attention to the content of the classroom, but also pay attention to the inner dynamics of students and the students' teaching model of English knowledge. Real needs and standards. Only in this way can teachers truly use the teaching methods to solve the problems encountered by students in actual English learning, and thus promote the improvement of students' English scores and the establishment of English core literacy. Under the background of education in the era of MOOC, college English should focus on the main position of students in the classroom, and stimulate the autonomy of students through teaching and learning, so that students are willing to delve into English language knowledge, so that students can learn from "I want to learn." "To change the learning concept of "I want to learn", under this teaching mode, students can actively explore their own English learning problems, and find problems and solve problems in time, and promote their overall improvement in English. In addition, teachers should also take a deeper guidance in combination with the students' learning effects, and organize students to carry out English cultural activities. Through the design and participation of teaching activities to correct their position in the classroom, from knowledge disseminators to interactive organizers Transform with participants.

The MOOC can fully realize online and offline communication, on the one hand, it highlights the student's subjective status, on the other hand, it can also enhance students' learning awareness. Based on the advocacy classroom under the background of Internet development, the traditional English classroom learning partnership has extended the relationship between teachers and students to extracurricular activities, thus solving many teaching problems. For example, students can better complete the assignments assigned by the teachers, teachers can more easily monitor and inspect the students' homework assignments, and use computers to help students correct the network, so that students can recognize the first time. The lack of self, the timely guidance of the teacher online can ensure the learning effect of the students, and let the teachers change from the disseminators of knowledge to the promoters and assistants of after-school reflection. It can be denied that the MOOC model, as a product of the combination of information technology and quality education, has many advantages that traditional teaching models do not have. Although it can break the limitations of time and space, and expand the learning conditions and scope of students, it is not a complete substitute 
for traditional classroom teaching. Traditional classroom teaching is mainly guided by a "face-to-face" approach. This kind of guidance can better explore the learning dynamics of students and the emotional communication between teachers and students. Emotional teaching can stimulate students' learning motivation and enable students to be in English. The learning is consistent, and the MOOC mode does not have this advantage. Therefore, it is not advisable to use the MOOC mode for effective English education. Only through the innovation of MOOC, such as creating a mixed classroom mode, the traditional "face-to-face" classroom teaching mode and the classroom teaching mode will be combined. The advantages and disadvantages between the two complement each other, so as to ensure the maximum quality of English teaching. Under the background of the era of MOOC, college English teachers should use the content of teaching materials reasonably to ensure the effectiveness of teaching. To this end, teachers should prioritize the investigation of students' interests and interests, and focus on the design of teaching programs and the selection of teaching contents according to the interests of students. . In the construction of the specific curriculum, the teacher should focus on the curriculum of the college itself, skillfully use the rich MOB curriculum resources, and reasonably extend the knowledge theory, so that students can improve their comprehensive ability in the process of self-selection and learning. As far as the MOOC course is concerned, its content is very rich, and the scope of the course is also very extensive. For this reason, teachers can use the teaching resources in the MOOC to develop English cultural activities, and the quality resources of the MOOC will be presented through the "face-to-face" teaching form. To give full play to the advantages of the mixed teaching model.

The construction of a scientific and rational curriculum evaluation system is an important guarantee to ensure the quality and effectiveness of English teaching in colleges and universities. In the English teaching of colleges and universities, teachers can use micro-courses to introduce new questions, and use video and video files to attract students' attention. Students are impressed by the active learning of English in this teaching environment. Taking the "festival" topic as an example, teachers can guide students to find historical data of Chinese and Western cultures during teaching, so that students can learn English knowledge based on the knowledge of historical background, thus accumulating more knowledge of listening, speaking, reading and writing. And to enrich the students' knowledge and cultural vision. Under the background of the era of MOOC, the forms and contents of English teaching are characterized by diversity. College English teachers should fully grasp this point and optimize the evaluation system of innovative courses as much as possible so as to comprehensively adjust "listening, speaking, reading and writing". "Evaluate students' comprehensive ability to use language. For example, in daily English learning, students can independently collect learning materials on the MOOC website and write corresponding learning experiences and learning outcomes. Teachers should carefully evaluate the self-study content of the students and correct the students' shortcomings in time. Students who have better tasks should also be encouraged and praised to stimulate their enthusiasm for learning. In addition, in daily classroom teaching, teachers should also pay attention to the learning exchanges with students. As a language subject, English should not only pay attention to students' academic achievements, but also pay attention to students' practical ability. Through evaluation and assessment of students' communication, it can make up for the shortcomings in traditional test-oriented education, thus optimizing teaching. Content, improve the effectiveness of English classroom teaching.

\section{CONCLUSION}

Under the era of MOOC, college English teaching presents a "kale flower tube" situation. How to deal with the transformation of teaching mode, the impact of massive resources and the problems of teachers and students are the main challenges facing the current MOOC. In the process of developing the MOOC in the new era, we must reform the MOOC curriculum system, do a good job of integrating online and offline teaching, continuously optimize the teaching resources of $\mathrm{MOOC}$, and form the content of high quality MOOC resources. At the same time, it is necessary to improve the quality of teachers and the quality of students to ensure that they can complete the task of teaching MOOCs with high quality, thus realizing the integration of MOOC and college English classroom teaching, and comprehensively promoting the development of college English teaching.

\section{REFERENCES}

[1] Zhang Nannan. Exploration and research of college English classroom teaching mode based on the era of MOOC[J]. Science and Technology Innovation Review, 2014, 11(36): 103-104.

[2] Li Jingyuan. Challenges and Opportunities for College English Teachers in Agents and Universities in the Case of Big Data Mu School Media[J]. China Press, 2017(02): 34-35.

[3] Shi Zhuanzhuan. Research on the Ability-oriented Teaching Model of College English Expansion Course in the Information Age - Taking the Workplace English Course as an Example[J]. Overseas English, 2017(04): 95-98.

[4] QIAN Yafeng, WANG Jinghong. Analysis on the Reform of College English Curriculum in Art Colleges under the Background of "Mu Class"[J]. Journal of Baicheng Teachers College, 2017, 31(05): 71-74.

[5] Liu Ping, Liu Yun. SWOT Perspective: Path Construction of College English Teachers in the Age of Mouth Class[J]. Journal of Anhui University of Science and Technology, 2017, 31(04): 102-107.

[6] Wang Xiuwen, Wu Yue. On the Current Situation and Development Opportunities of College English Education under the Wave of MOOCs[J]. Foreign Languages \& Translation, 2016, 23(02): 71-75. 